\title{
Vital Signs Test Code
}

National Cancer Institute

\section{Source}

National Cancer Institute. Vital Signs Test Code. NCI Thesaurus. Code C83466.

A character or string that represents the short code name of the vital signs test. 